\title{
BODY-SOUL AND THE BIRTH AND DEATH OF MAN: BENEDICT HESSE'S OPINION IN THE MEDIAEVAL DISCUSSION
}

The recent decades of research on mediaeval theories of the soul supply a considerable number of extensive and profound studies together with editions of relevant source texts; a significant part of these works concern the heritage of late mediaeval thinkers among whom the leading role was played by the Parisian philosopher John Buridan and his continuators, among others, Nicole Oresme and Marsilius of Inghen. ${ }^{1}$ They disseminated in Europe new epistemological-methodological conceptions and together with these, changes of the paradigm regarding science of the soul. These resulted in effect in a struggle for the new sharp epistemological criteria presented by the inceptor of the terministic and nominalistic current, William of Ockham, and the attempt to integrate them with the already worked out scholastic psychological theories.

Due to the fact that mediaeval philosophical psychology develops both from the heritage of Aristotle's De anima as well as from the typical problems of Christian doctrine, this double context did not facilitate for scholars the solution of postulates intensifying the exigency of science, posed by Ockham's criticism. This implied an accumulation of difficulties and the appearance of new aporias regarding both methodology as well as the contents.

In my paper I would like to widen the spectrum of the late mediaeval discourse on psychological problems by presenting selected views on the subject of its later participant, an eminent Cracovian scholar, Benedict Hesse

Prof. Dr. habil. WANDA BAJOR - The John Paul II Catholic University of Lublin, Faculty of Philosophy, Institute of Philosophy, Department of the History of Philosophy in Poland; e-mail: bajor@kul.lublin.pl; ORCID: https://orcid.org/0000-0003-2121-0608.

${ }^{1}$ These are, among others, the works of such authors as Jack Zupko, Sander W. de Boer, Benoît Patar, Guyla Klima, Paul J.J.M. Bakker, and Johannes M.M.H. Thijssen. 
(1389-1456). He is regarded as a follower of Buridan's philosophical tradition, albeit in the spirit of solutions offered by the $13^{\text {th }}$ century tradition (the so-called via antiqua), and is therefore labelled as belonging to the current called via communis (see MARKOWSKI 2008). Hesse is the author of an extensive commentary on De anima which he composed on the basis of a relevant text by the Scottish philosopher Lawrence of Lindores, a student of John Buridan (see Benedict Hesse 2011). ${ }^{2}$

Taking into account the European doctrinal context from which Hesse's psychological commentary emerges, I shall take up two traits which he presented in connection with the problem of the "mind-body" relation, discussed in the framework of the paradigm of the psycho-physical unity of man: 1) birth, as connection of the body and the soul, and 2) death, as the separation of the body and the soul, together with the related problem of anima separata. ${ }^{3}$

\section{ORIGIN - BIRTH OF MAN}

For mediaeval commentators of the Aristotelian theory of the soul contained in the De anima treatise, the problem of the birth of man is linked to the fundamental problem of the relation of the soul to the body as well as the ontological status of both correlates of this relation. As regards the question of the soul's (i.e. the intellect's) origin, the scholastics accepted (as developed in Christian antiquity and based on the Bible) the creationist concept ${ }^{4}$, agreeing all that it is created and introduced by God into the human body (embryo), without describing the moment in time when this happens. One of the key difficulties in this context was the understanding of the body (i.e. matter) which, in accordance with the accepted and defended hylemorphism of Aristotle, creates a substantial unity with the soul. On the authority of Aristotle that in order to receive a given act a subject must be adequately disposed (cf. Arist. De an., II, 2, 414a 21-22 = ARIstoteles 1831a, 215), mediaeval commentators, in their majority, agreed with the thesis that, in the

\footnotetext{
${ }^{2}$ Hesse's opinion in the discussion on the subject of the immortality of the soul was elaborated by Brigitte Burrichter and Thomas Dewender (see BURRICHTER and DEWENDER 1988).

${ }^{3}$ Problems connected with the soul- body problem are a subject of profound studies, as e.g. in $13^{\text {th }}$ century tradition see BIENIAK 2010; in the $14^{\text {th }}$ century - see DE BOER 2013; ZUPKO 1993.

${ }^{4}$ Patristic authors discussed the problem of the beginning of man in the context of inheriting original sin. Apart from creationism, traditionalism was adopted, which stated that the soul is created along with the body at the moment of conception. See DA CRUz PONTES 1964.
} 
moment of uniting with the soul (form), the matter of the body must be ready, that is, formed to a certain extent for the soul's reception. In addition, those who accepted the unity of form in each substance, were all the more in a difficult situation: they had to answer the question about the nature of this matter if, being ready to accept the form, it is not a pure potentiality (should one accept that it is somehow actualised, how could it create a substantial unity with the form - soul?). It seems therefore that the joining of the soul with actualized matter makes it an accidental form and thus denies its substantiality.

The issue of the human beginning, discussed on the basis of the Aristotelian science of the soul, was related to the problem of the multiplicity of forms originating from the Judeo-Arab tradition (especially based on Avicebron's Fons vitae); this was implicit in the contemporary theory of embryogenesis. Aristotle provokes this issue in his biological treatises, where he states that both human and animal embryos manifest forms of vegetative and sensual life, while the human rational soul (nous) does not arise from the potency of matter, because, having a divine nature, it comes from outside. ${ }^{5}$

This view convened and could be combined with the Christian teaching on the creation of the human soul. On the other hand, the main difficulty resulted from the question of whether from the moment of a human's embryonic development we are dealing with three types of forms, meaning vegetative, sensual and intellectual, or whether there is one substance (form) manifesting itself in its functions (vegetative, sensual, intellectual). Scholastics solved this problem in various ways. Some defended the multitude of forms, others fought for the unity of the soul (form). William of Auvergne adopted the thesis on the succession of successive forms: both forms, the vegetative and the sensual, perish when the rational soul is introduced, which Thomas Aquinas accepted and developed as the doctrine of the succession of forms (see DA CRUZ Pontes 1964, 203-204, more see 199-120). His master, Albert the Great, defended the substantial unity of the soul, stating that there is one form starting at the beginning of human life, whereas in the embryo, it can be known through its functioning, first by performing vegetative and then sensual activities (see DA CRUz PonTes 1964, 220).

Fourteenth century scholars undertook a new the discussion regarding the theme of the substantial relation of the soul and the actualized body, bearing

5 " [...] restat igitur ut mens sola extrinsecus accedat, aeque sola divina sit. Nihil enim cum eius actione communicat actio corporalis." (Arist. Gen. an., II, 3, 736b29 = ARISTOTELES 1831b, 360). "[...] et is intellectus separabilis est et non mistus, pasioneque vacat cum sit substantia actus. [...] Separatus vero id est solum quod est, atque id solum immortale perpetuumque." (Arist., De an., III, 5, 430 a $10-25=$ ARISTOTELES 1831a, 223). 
in mind the revolutionary postulate of Ockham, that the contention about the immaterial and indestructible soul as a form of the body is true on the authority of faith, but is not philosophically provable (see William Ockham, Quodlibeta septem, I, q. 10, q. 12 and q. 16; II, q. 10 and q. $11=$ WiLLIAM OCKHАM 1980, 62-65, 68-72 and 87-90, 156-162 and 162-165). And so, although the $14^{\text {th }}$ century interpretations contain the basic framework of concepts worked out by predecessors, they are still subject to serious modifications and constitute different variants of more and more subtle solutions of particular ideas evolving towards a remodeling of the scientia de anima itself.

We also see this in the tendency of narrowing the metaphysical aspect in favour of widening the field of psychological research in the direction of natural-philosophical science, among others by reaching beyond the De ani$m a$ treatise itself to include not only the De generatione et corruptione but also other natural texts such as the Physics. ${ }^{6}$

The notion of the union of a body and the soul and the moment in which it occurred was a problem of the great importance from the point of view of Christian doctrine, which proclaimed the immortality of the soul, and its continued individual identity (after the separation from the body) well as the resurrection of the body. In order to defend this dogma of faith in context of Peripathetic philosophy, one needed to discover the principles conditioning it inherent in man's nature right from the beginning of his existence. A Christian philosopher had to justify that the soul may have a being not only as a human soul in general, but as an individual soul of a given human being, in such a way that it joined, in an essential way, the human body (in Aquinas' words - habitudo animae ad hoc corpus). ${ }^{7}$ For this to be assured the human body must be mature enough to receive a rational soul from the moment of man's origin, already in the stage of an embryo, so that it could be joined to a definite body (embryo) and not another.

For comparative purposes, I shall mention briefly selected terminological distinctions from Thomas Aquinas' theory of the soul developed by his students (among others, Caietanus, Giles of Rome) ${ }^{8}$, concentrating on what interests me, namely the notion of the human body considered in the aspect of its relation with the soul.

\footnotetext{
${ }^{6}$ The problem of the theory of science regarding the soul is discussed extensively in de BOER 2013, see also KING 2017.

${ }^{7}$ See Thomas Aquinas, De spiritualibus creaturis a. 9, ad. 4 = Thomas Aquinas 2019a, \#64305.

${ }^{8}$ An example of bringing together Buridan's solutions and the ideas of the Thomistic school may be the anonymous commentary on the De anima found in the Jagellonian Library (BJ 1987) entitled ,secundum scholam Buridani”, which very often refers to the ideas of Giles of Rome.
} 
Thomas Aquinas used subtle distinctions; when referring to the notion of the body; in the aspect of the origin of man, the term corpus humanum has at least two meanings. Firstly, Aquinas by corpus understands the embryo, which refers to the phase of development before the reception of the human soul (rational soul); Aquinas does not define the moment when this happens. The embryo is made up of the first matter and of the form; when God creates the rational soul for a certain embryo, the form of the embryo concedes its place to the rational soul which now takes over all the functions of the embryo and, in addition, takes on others, ones which are proper to it as a rational soul and from now on it constitutes the form of the human compositum. The body, therefore, with which the rational soul unites is a complete being, made up of the first matter and the form, it is a complete material being, a composition which is the human embryo; it is the matter prepared so to say by the human embryo for the infusion into it of the rational human soul. Secondly, by the term corpus Thomas understands the first matter taken in the aspect of generation and corruption which are substantial changes. the moment of the infusion of the human soul into the prepared body is, as he thinks, a process spread out in time: the old substantial form perishes and a new one appears. In such types of substantial changes the unchanging subject may only be the first matter, as opposed to accidental changes (alteratio), in which the subject is a complex being. Thus, when the human embryo by the working of the introduced rational soul becomes the body of man, we are dealing with a regress to the status of the first matter, as an unchanging element which is the subject of substantial changes. Understood in such a way, corpus refers to the human being in all its extensibility and not only to the embryonic period (see Wielgus 1983, 122-123).

Thomas made subsequent terminological distinctions (which his students developed) regarding the human body, in solving the problem of the individuation of the soul and, in connection with this, the problem of the identity of the subject, expressed as the: commensuratio animae ad hoc corpus. Here we have two kinds of matter: the first is the materia communis (constituting the essential part of the species) understood as potentiality in respect of various acts (forms), constituting the foundation of the differentiation of genus; the second kind is the materia quantitate signata (as an element in the individual) depending on the division made by the quantity, constituting the principle of numeric differences. Whereas differences of species always come from the form, it is not the matter defined numerically which assures the identity of a given individual, as it changes during its life. The substra- 
tum assuring the identity of a given individual being is the materia communis, by virtue of the so-called commensuratio, which belongs to the essence of the soul (only differing from it in thought). This signifies the adaptation of the soul to the body (substantialis coaptatio as a property imparting a position and dimensions) and decides about the definite form of an individual man, also after death, that is, its separation from the body. ${ }^{9}$

The difficulty being such that in the process of human birth the formed matter specified as regards quantity (quantitate signata) precedes the substantial form (soul), Aquinas and his pupil John of St. Thomas solve it by accepting two orders: the order of nature (essence) and the order of existence. In the order of existence the first is the substantial form (soul), but in the order of essence (essentiae), the first is matter specified as regards quantity. ${ }^{10}$

A recapitulation of the above mentioned concepts of Thomas may be the words of R. Pasnau who ascertains that: "Aquinas holds in general that the various actualities that comprise any substance always flew from the essence of that substance" (PASNAU 2007, 16). Elements of Thomas' psychological doctrine are to be found in commentaries of late mediaeval scholars, although they do not always directly mention him as the methodological requirement of that time did not compel an explicit quotation of authors.

${ }^{9}$ Thomas uses the concept "commensuratio" in various contexts in order to describe certain quantitative norms; however, in refereing to the human body he mainly used the terms "habitudo", "proportio" or "aptitudo", e.g.: ,[...] licet anima humana non habet materiam partem sui, est enim corporis; et ideo quod quid erat esse suum includit habitudinem ad corpus." Thomas Aquinas, Quaestio disputata de anima, a. 1-13 = Thomas Aquinas 2019b, \#64448 - \#64917; "Forma quodammodo est in materia inquantum habet aptitudinem et ordinem ad ipsam." THOMAS Aquinas, In librum B. Dionysii De divinis nominibus expositio, 4, 9, V = Thomas Aquinas 2019c, \#84852; "Non est igitur possibile quod anima canis ingrediatur corpus lupi, vel anima hominis aliud corpus quam hominis. Sed quae est proportio animae hominis ad corpus hominis, eadem est proportio animae huius hominis ad corpus huius hominis. Non est igitur possibile animae huius hominis ingredi aliud corpus quam istius hominis." Thomas Aquinas, Summa contra Gentiles, II, 73, 4 = Thomas AQUINAS 2019d, \#25146. Whereas Caietanus elaborated a precise analysis of the term "commensuratio" in his commentary on Thomas' treatise De ente et essentia, using also the terms: „inclinatio, aptitudo, coaptatio, sigillatio, proportio." See Caietanus (Thomas De Vio), De Ente et essentia D. Thomae Aquinatis Commentaria, 273, XIII = Caietanus (Thomas De Vio) 1934, 273. (See SwIEŻAWSKI 1948, 169-171).

${ }^{10}$ Thomas introduces two types of dimension into the problem of individualization: 1) undetermined (sine determinatione) 2) determined as regards greatness and shape (secundum terminatam mensuram et figuram); the last, according to Thomas, cannot constitute a principle of individualization, because being in a constant change of these dimensions in an individual, it would be deprived of identity with itself in the sphere of its duration. (See SwIEŻAwSKI 1948, 139; FOREST 1956, 237-239). 


\section{JOHN BURIDAN}

Buridan emphasized the transcendent dimension of the subject of science of the soul; in the most difficult questions, especially of the relation between the human soul and body, he did not conceal the limitations of his approach. However, he opposed the Ockhamistic option which denies psychology a scientific status as well as the skepticism of his contemporary opponents, basing himself on his own postulates of epistemological solutions. Whereas as regards the most difficult philosophical themes, such as the relation of soul and body, he had the courage to acknowledge the limitations of the human mind and to submit to faith, demonstrating at the same time the rational character of its doctrine. In his opinion, this also constitutes the role of a philosopher. Moreover, theological truths allow the human intellect to surpass the limits of natural philosophy and so freeing it for speculation on the subject of possible worlds (see Sylla 2001), 222; ZUPKO 1993, 596-597; JOANNES BURIDAN 1991, 184*-191*). ${ }^{11}$ This may be the result of the general $14^{\text {th }}$ century tendency to remove natural philosophy together with psychology belonging to it, from metaphysics, which seems in a certain sense to be replaced by reference to theological argumentation.

In late mediaeval commentaries on the De anima, the principal problems concerning the nature of the soul and the body its mutual relations were discussed above all in the context of the definition of the soul. As present-day scholars emphasize, in the $14^{\text {th }}$ century commentators on the Aristotelian theory of the soul concentrated on the problem of the definitional dependency of the soul on the body, which was connected to intensive logical analyses as well as to the problem of the nature of the body itself, constituting one of the component elements of the definition of the soul (see DE BOER 2013, 162).

John Burydan, in the analyzed definition of the soul which he entitled: "Anima est actus primus substantialis corporis physici organici vitam habentis in potentia" (JoAnnes Buridan 1991, 240), ${ }^{12}$ accepted the concept, known in speculative psychology, of a body understood as formed matter; though the understanding of the meaning of "formation" remained an open question. $\mathrm{He}$ used in this context the concept of "first matter," but under the stipulation

${ }^{11}$ The methodology and epistemology of Buridan are the subject of most recent studies, as e.g.: ZuPKo 2003; De BOER 2013.

${ }^{12}$ See also: Thisssen and ZuPKo (eds.) 2001, 40 [cf. Arist., De an., II, 1, 412a 19-21 and 27-28; 412 b 5-6]. 
that it is not a type of "pure" matter, because such matter (materia pura) is incapable of accepting a form (see JoAnNES BURIDAN, 1991, 138*). Following by Aristotle's thesis that the soul cannot come to exist in any body, but in a determined body, he asserted that a soul needs accidents which would predispose the matter to accept it. In order to accept a substantial form, matter must be appropriately fashioned (materia disposita) and made ready by accidental qualities (actuata per qualitates accidentales); it must possess a certain number of accidents which make it capable of being formed. ${ }^{13}$ These accidental forms precede in time the reception of the substantial form, in other words, the soul into the matter of the body (embryo). The Parisian master points out here a certain analogy with the cognitive activities of the intellect: before it may come to know substance, the active intellect, should be made disposed and ready by knowledge of the accidents through the intermediary of the potential intellect. ${ }^{14}$

In referring to the question, whether the soul is indeed the first act of the body because it is preceded in time by accidental forms, Buridan based himself on Thomas' solution. Having accepted the difference of the order of essence and the order of existence, the primacy of the soul is qualified in the order of essence, that is, in its perfection as the first act of the body, the act which constitutes the source of life activities. At the same time, Buridan notes that it is superfluous to raise such a doubt, as Aristotle's own term "substantialis," says that a substantial form is first in the order of perfection in relation to accidents. ${ }^{15}$

13 JoAnnes Buridan, Le traité de l'âme, 42 (= JoAnnes Buridan 1991, 42): “[...] de forma substantiali non debet intelligi quod forma recipiatur in nuda materia, immo recipitur in materia disposita et actuata per qualitates accidentales; ibid., 232: "Anima praesupponit accidentia disponentia materiam ad receptionem eius; ergo animam praecedunt qualitates disponentes materiam [...] anima non fit indifferenter in quolibet corpore, sed fit in corpore determinato; quod non esset, nisi anima praesupponeret determinatas dispositiones materiae in qua debet recipi."; ibid., 518: "[...] materia prima non potest recipere formas substantiales nisi disposita et praeparata per accidentia $[\ldots] . "$

${ }^{14}$ Ibid., 518: "[...] sicut materia prima non potest recipere formas substantiales nisi disposita et praeparata per accidentia, ita etiam intellectus, antequam recipiat notitiam substantiae [...] indiget disponi et praeparari per notitias accidentium. Et sicut agens naturale in materia praeparata potest extrahere formam substantialem ad actum, ita intellectus agens, cum intellectus possibilis praeparatus fuerit per notitias accidentium, potest extrahere ad actum notitiam substantiae."

${ }^{15}$ Ibid., 236: "Patet quia inter omnes actus qui sunt in materia, ipsa anima est actus perfectior, quia est substantia; ergo bene est actus primus via perfectionis. Ista conclusio quamvis sit vera, tamen non est ad intentionem Aristotelis, nam tunc frustra adderetur li substantialis cum dicitur: «anima est actus primus substantialis corporis physici, etc», ex eo quod esse actum via perfectionis respectu accidentium est commune omni formae substantiali." 
Describing the role of man in the process of birth, Buridan affirms: "Your father does not generate you in other way than by producing semen by which the matter is disposed to receive your form." ${ }^{16} \mathrm{He}$ exemplified it using the following instance: If a horse which has produced semen suddenly dies, this does not constitute an obstacle for the semen to generate a horse. In this aspect, a human being generating a human being does not possess a more perfect action than that of a donkey generating a donkey. Neither of these generates differently than by producing semen which prepares the matter. An animal does not give birth to another animal as the first (essential) cause (principale agens), but only as the supplier of semen (ministrans semen $).{ }^{17}$

Thus, Buridan also declares: "I do not believe that a soul giving birth in such a way is a directing factor in giving birth to someone similar (sibi similis), it is solely a directing factor in giving birth of the semen." ${ }^{18}$ In this sense too, we speak of a man as "father" who has the power of giving birth in the vegetative dimension, capable of producing semen, which is the essential part of the progeny. ${ }^{19}$ Whereas, the essential factor producing (producens) the human soul or that of a donkey [sic!] is different from the man or donkey, it is the separate substance, namely God (substantia separata ut Deus). ${ }^{20}$ The rational soul (intellect) is infused into man by the Creator (infusa per Creatorem), and not drawn from matter. ${ }^{21}$ Buridan reinforces the thesis by referring to the twelfth book of the Metaphysics: "but the first thing is not the semen, but a perfect being." 22 In refuting as extreme the two opinions regarding the nature of the soul and its relation to the body-that of Averroes as well as of Alexander of Aphrodisias-he accepts a middle solu-

${ }^{16}$ Ibid., 546: "Ad aliam dico, quod pater tuus non aliter genuit te nisi quia produxit semen per quod materia disponitur ad receptionem formae tuae."

${ }^{17}$ See ibid., 546.

${ }^{18}$ Ibid., 571: "Non credo quod anima sic generantis sit principale generans sibi similis, sed solum generat semen: unde post generatur sibi simile; et ideo anima est potentia principaliter generativa seminis."

${ }^{19}$ See ibid., 804.

${ }^{20}$ Ibid., 546: „Et ex hoc etiam responsum est quod asinus non habet nobiliorem operationem in generatione asini quam homo in generatione hominis, quia neuter generat nisi producendo semen quod $\mathrm{pr}<\mathrm{a}>$ eparat materiam, et agens principale producens animam hominis vel asini est aliud ab homine vel asino, quia est substantia separata ut Deus, sicut debet videri XI ${ }^{0}$ Metaphysicae." It seems that in this fragment Buridan in contending that even the soul of a donkey comes from God, applies Thomas' principle of universal causation.

${ }^{21}$ Ibid., 417: „Sed secundum veritatem concedendum est quod est forma substantialis inhaerens corpori, non tamen educta de potentia materiae, sed infusa per Creatorem."

${ }^{22}$ Arist., Metaph., XII, 7, 1073a 3-4 (= Aristoteles 1995, 529). 
tion which, in his opinion, is recommended by faith (fides autem nostra tenet medium). ${ }^{23}$

The methodological and doctrinal considerations of John Buridan, which were popular and disseminated across Europe in the first half of the $15^{\text {th }}$ century, were adapted and developed creatively in the University of Cracow where, among other subjects, psychology was taught based on the commentaries of Buridan. In this field Benedict Hesse and his students had a wide influence, they left a rich commentary heritage belonging to the so-called Cracovian Buridanism.

\section{BENEDICT HESSE}

The late mediaeval Cracovian scholar, Benedict Hesse, linked in his commentary on the De anima the interpretation of two traditions: the socalled via antiqua referring to the ideas of its main authority, Thomas Aquinas, with the philosophical postulates of the so-called school of Buridan, remaining under the particular influence of the works of Lawrence of Lindores and Marsilius of Inghen.

\section{- METHODOLOGICAL DEMARCATION}

From the methodological as well as the gnosiological side, Benedict followed the theories elaborated by John Buridan and his outstanding pupils. From them he took the threefold criteria of truth: (1) the way of natural light (lumen naturale), (2) the way of philosophy (secundum viam philosophorum), (3) and the way of faith (supernaturaliter et opinio fidei) - the last is identical to truth - and deserves not so much to be called an opinion, but more so the truth which is the Catholic faith (quae non meretur dici opinio, sed magis veritas, quae est fides catholica) (BENEDICT Hesse 2011, 367-368). Following Londorius, Hesse quoted the definition of natural light (lumen naturale): Natural light is the truth by which one may oneself gain true knowledge without the cooperation of the First Cause, but with the general cooperation of the world which is above the heavens. ${ }^{24}$ The way of natural

\footnotetext{
${ }^{23}$ Ibid., 418.

${ }^{24}$ Benedict Hesse, Quaestiones disputatae (ed. Bajor), 367: "Respondetur, quod lumen naturale dicitur esse veritas, per quam quis potest attingere suis propriis viribus sine speciali concursu primae causae, sed cum influentia supercaelesti generali. [...] Lumen naturale est veritas." Buridan used the
} 
light (having an absolute probative force) is identical to truth, it cannot therefore lead to errors, and if so, should refrain from judgement in matters in which it arrives at theses contrary to faith. This in particular concerns the most difficult metaphysical problems regarding the soul, so that one might not give in these problems a decisive answer. However, philosophers reach further and do this in a conscious and methodic way. When one cannot undertake a solution on the natural way of such problems as e.g. the union of the soul with the body, further speculation should be transferred to a different plane of research, which is the truth of faith (see Benedict Hesse 2011, $244 *-246 *)^{25}$

According to Benedict, the truth is only given by Christian faith and natural light, whereas the opinions of philosophers are only true insofar as they agree with these criteria. These opinions, together with the views of Aristotle, do not possess such probative force as the dogmas of faith and natural light and are subject to these. They solely are supported by convictions (persuasiones) and do not possess such a probative force as affirmations gained with the help of lumen naturale. ${ }^{26}$ Affirmations educed from natural light, from the first principles, from sentences obvious through themselves, are based on proofs (demonstrationes). In this way a loosening of ties between philosophy and theology occurs in Hesse, but also between philosophy itself and the standpoint of particular philosophers. This constituted a further step following Buridan, on the way leading to the freeing of philosophy from the overwhelming domination of Aristotle (See MARKOwSKI 1988, 247-249; MichalsKi 1921, 283).

And so in the most difficult questions regarding the soul, the Cracovian scholar acted applying the distinguished criteria of truthfulness and the plane

term ratio naturalis, which he thought to be with the truths of faith, instead of the notion of ,natural light"; See JOANNES BURIDAN 1991, 675-677; whereas the Cracovian scholar Paweł of Worczyn used both the notion of lumen naturale, as well as Buridan's term ratio naturalis placing it on the same plane as ratio fidei. See KuKSEwICZ 1975, 221.

${ }^{25}$ BenEDict Hesse, Quaestiones disputatae (ed. Bajor), 368: “[ ...] multum refert loqui secundum viam philosophorum et loqui secundum viam et lumen naturale. Patet corollarium, quia secundum viam philosophorum multa falsa sunt concedenda [...]. Modo talia in lumine naturali non sunt concedenda. Modo ad propositum dicitur, quod ista materia de intellectu humano, quae sunt dicta, excedit notitiam luminis naturalis, et ergo stans in lumine naturali potest se excusare de responsione ad istam materiam".

${ }^{26}$ Ibid., 378: "Modo dicitur, quod recta ratio Commentatoris dictat dialectice intellectum non inhaerere et sophistice, non autem demonstrative. Et ergo cum ratione Commentatoris probationis dialecticae potest stare suum contradictum, quia dialecticae est probativa utriusque partis contradictionis." 
of discussion. Using on occasion the term: "supernaturaliter loquendo", he openly gave up certain fields of psychology to theology. Such practice shows that his standpoint is in harmony with the convictions of $14^{\text {th }}$ century philosophers that - as S. de Boer recapitulates - philosophical cognizance arrived at its borders (see DE BOER 2013, 291-292).

\section{— THE HUMAN BODY}

Returning to the concept of the human body, it should be emphasized that Hesse devoted considerable attention to this problem, also in the commentary on the Physics. In the questions regarding the De anima in the context of analyses of the definition of the $\operatorname{soul}^{27}$, he gave the following systematization of the notion of body: 1) In the first sense, the body was understood as a category of substance (de praedicamento substantiae), and this in a twofold sense: firstly, as a body composed of matter and form, in this sense man was a body; secondly, as a body understood to be a material part entering into a composition, that is, matter described by the name of body. 2) In the second sense, we understand the body by the category of quantity (de praedicamento quantitatis) and here again in a twofold manner: in an abstract sense together with three characteristics - length, width, depth and in a concrete sense, as a three-dimensional (extensive) thing, possessing the above mentioned three accidents. ${ }^{28}$

\section{- FORMED MATTER}

As regards the moment of man's coming into being, Hesse admits that this takes place when God creates for a formed human embryo a rational

\footnotetext{
${ }^{27}$ Buridan's three types of definitions: a quidditative definition, a nominal definition (quid nominis) and a causal definition, Hesse supplemented this with a fourth-descriptive one and explained that each being may only possess one essential definition (essentialis et quidditativa), but this same being may also be defined by other kinds of definitions - causal and descriptive (causales et descriptivae). These definitions present a given being in different aspects, according to the multiplicity of its accidents, as each being possesses one essence and many accidents. (See Benedict Hesse, Quaestiones disputatae (ed. Bajor), 249*-251*; see De Boer 2013 , 163).

${ }^{28}$ Benedict Hesse, Quaestiones disputatae (ed. Bajor), 42: „Corpus causatur dupliciter: Uno modo, ut est de praedicamento substantiae, et sic capitur dupliciter. Uno modo corpus dicitur compositum ex materia et forma, et sic homo dicitur esse corpus. Alio modo capitur pro parte materiali compositi, et sic materia dicitur corpus. Alio modo capitur corpus, ut est de praedicamento quantitatis, et hoc dupliciter. Uno modo abstractive, et sic est longitudo, latitudo et profunditas. Alio modo concretive, et sic est longum, latum et profundum"; These problems were discussed in detail in the commentary on the Physics, see Wielgus 1983, 121.
} 
soul; there is therefore no mention of a joining of the soul (substantial form) with the first matter as a pure potentiality and something undefined. Hesse uses in this context the notion corpus in the first of meanings given above, a Thomistic understanding of the term, as matter prepared for the reception of the soul. The rational soul unites as an act with the embryo, which is already matter finding itself in a formal act. Hesse describes the body, embryo, in the quantitative category in its concreteness, calling it an extensive material thing (res extensa). He excludes the understanding of the body in an abstract sense, arguing that the postulated substantial psycho-physical unity of the human being would only have an accidental status, because the body so understood constitutes an accidental and hence the soul, being a substance and the body only an accidental would make an accidental unity. Hesse also analyzes in what sense we may speak of a substantiality of the body which is united with a rational soul. Taking into account the division of the meaning of the term "body" accepted above, he states that we may speak of the body substantialiter not in the sense of a complete composition (non pro toto composito), but understanding it to be one of the parts of the composition (sed pro altera parte composite). Only understood in such a way, the body (matter) may constitute a substantial unity with the soul. ${ }^{29}$ Benedict ascribes to the matter of the embryo a formal accidental act (accidentalis) and not a substantial one (substantialis). It is formed matter, described by accidental forms, predisposed by disposing qualities (disposita per qualitates dispositivas). Hesse addend an explanation saying that if one may speak of an act of the body then it is an act understood as actus praesentiae and note actus

${ }^{29}$ Benedict Hesse, Quaestiones disputatae (ed. Bajor), 50: “«Corpus» non debet hic capi substantialiter, scilicet pro toto composito, quia sic, ex parte et toto fieret unum. Sed debet capi quantitative et non debet capi abstractive, sed concretive, scilicet pro re extensa vel pro materia extensa [...] Et dicitur notanter, quod [corpus] non debet hic capi abstractive, quia si corpus caperetur abstractive, tunc ex corpore et anima fieret unum per accidens, quia corpus caperetur quantitative et abstractive, tunc ex corpore et anima fieret unum per accidens, quia corpus captum quantitative et abstractive est accidens et anima est substantia. Modo ex anima et substantia fit unum per accidens. Vel alio modo potest dici, quod corpus potest capi substantialiter non pro toto composito, sed pro altera parte compositi, et sic ex corpore, id est ex materia fit unum per se"; ibid., 42: "Modo dicitur, quod anima est actus corporis tam de praedicamento substantiae quam etiam de praedicamento quantitatis; est enim actus corporis de praedicamento substantiae primo modo, non per inhaesionem, quia sic plures formae essent in eodem, quia est pars formalis compositi. Sed est actus corporis de praedicamento substantiae per inhaesionem, eo quod anima inhaeret materiae. Etiam est actus corporis de praedicamento quantitatis, et hoc capiendo corpus concretive, non autem abstractive." We have here an analogy to Thomas' concept materia quantitate signata, used together with the concept materia communis as regard the problem of individualization. (See DE BOER 2013; SWIEŻAWSKI 1948, 134-154). 
formalitatis. ${ }^{30}$ In this sense, the form does not come to the being existing in the formal substantive act, but in the accidental act. ${ }^{31}$

The understanding of formed matter as something assuming the existence of form which, before the introduction of the form - soul, is the form of the embryo, caused a contradiction with the principle stating that two substantial forms cannot subsist in the same subject. Benedict Hesse accepted in this question Thomas Aquinas' theory, adapted by Buridan, on the subject of the passage in the development of the embryo from a lower to a higher form. This consisted in the fact that at the moment of infusion of the human soul into the prepared body, the old accidental form perishes and the new substantial form appears. ${ }^{32}$ Therefore at the moment of the introduction of the form (soul), the form of the embryo is destroyed (in adventu formae in materiam dispositam, tunc forma embrionis corrumpitur). ${ }^{33}$ As regards the accidents themselves, that is, the qualitative dispositions (dispositiones qualitativae) Hesse upholds Buridan's opinion that they remain in the embryo's matter.

Hesse presented the origin of man in a similar way in the commentary on the Physics, where he presented the preparation of matter for the reception of the form in a twofold way: (1) In the aspect of its part, and in this sense matter is not successively prepared for the entering of the human form. (2) In the aspect of the preparation of the matter in a higher and higher degree (magis et magis), as well as regarding action - in this sense matter is prepared for the entry of the human form. ${ }^{34}$ As regards matter sufficiently prepared for the reception of the form, there are two understandings: (1) In relation to the disposition of the form - in this sense the intellect enters into

${ }^{30}$ See Benedict Hesse, Quaestiones disputatae (ed. Bajor), 53-54.

${ }^{31}$ Ibid., 14-15: „Tamen istae qualitates dispositivae praesupponunt formam, quia antequam forma introducitur, tunc ibi est forma embrionis, respondetur, quod in adventu formae in materiam dispositam, tunc forma embrionis corrumpitur, eo quod non possunt stare duae formae in eodem supposito, et sic forma non advenit enti in actu formali substantiali, sed accidentali."

${ }^{32}$ Ibid., 373: „Differentia est inter formam substantialem et accidentalem, quia forma substantialis recipitur in subiectum potentiale non actuatum completa, cum hoc tamen stat, quod recipitur in subiectum actuatum actuatione incompleta, scilicet per qualitates dispositivas. Et ergo si dicitur: «Materia non stat nuda, et ergo habet formam», hoc est verum. Tamen ex isto non infertur, quod tale subiectum sit actuatum actuatione completa, quia adveniente nova forma prior forma abicitur, et non remanet ibi forma primo modo. Et ergo primum instans novae formae est ultimum instans non esse prioris formae."

${ }^{33}$ Ibid., 15.

${ }^{34}$ Benedict Hesse, Quaestiones super octo libros (ed. Wielgus), 512-515: „Alio modo quo ad dispositionem magis et magis et operationem, et sic materia successive disponitur pro introductione formae humanae, quia materia aliqualiter disponitur pro introductione formae et postea magis disponitur." 
matter after its sufficient preparation. (2) In relation to a proper execution of its functions - in this sense the intellect does not enter after the sufficient preparation of the matter, because it would be entering into one part sooner than into the other, thus first into the heart, etc. The intellective soul, therefore, does not enter into matter successively, but comes into it in one moment after its sufficient preparation regarding all parts. ${ }^{35}$

\section{— THE NOTION OF GIVING BIRTH}

In the question Utrum homo generat hominem et sol, Hesse ask what is the correct meaning of the words "man generates man". In replying he asserts that in order to generate a man, it is necessary for the producing factor to prepare matter for the reception of the form of that which is to be born. Hence he concludes that man generates man in a twofold sense: formally, in this sense that he gives a suitable matter for the introduction of the form of that which is to be born, and virtually, in this sense that he generates it before it commences its existence. ${ }^{36}$ So too, strictly speaking, man does not generate man because he does not give birth neither to matter, nor to form, but only directs (administrat) these processes, which make the matter capable of introducing the form into it; it gives the matter of semen, which prepares the matter for the introduction of the form. ${ }^{37}$

We can find an extended analyzes of the above issues in the writings of Albert the Great, whom Hesse quoted in his commentary on De anima and

${ }^{35}$ See ibid., 514-515; ibid., 515: "Materia dicitur esse sufficienter disposita dupliciter. Uno modo quo ad dispositionem formae, et sic intellectus introducitur in materiam post sufficientem dispositionem materiae. Alio modo quo ad sufficientem operationem exercendam, et sic intellectus non introducitur post sufficientem dispositionem materiae, quia introducitur primo ad unam partem quam ad aliam, sicut primo ad cor ex eo, quod cor est primum vivens et ultimum moriens. Et sic ad argumentum dicitur, quod anima intellectiva non introducitur successive, et dicitur ulterius, quod introducitur post sufficientem dispositionem materiae quo ad omnes partes materiae."

${ }^{36}$ See Benedict Hesse, Quaestiones disputatae (ed. Bajor), 67; Benedict Hesse, Quaestiones super octo (ed. Wielgus), 229-230: “[...] quod homo generaretur, [...] requiritur, quod ipsum producens sufficienter disponat materiam pro susceptione formae rei generandae. Et ergo homo non generat materiam, nec formam, sed transmittit materiam in locum suum bene dispositam; ex qua transmissione homo dicitur generare hominem. [...] Homo non generat formaliter hominem, sed solum virtualiter, et generat hominem antequam incepit esse. Quod generat formaliter quia homo dat sufficientem materiam pro introductione formae rei generandae.” See WIELGUS 1983, 122.

${ }^{37}$ Benedict Hesse, Quaestiones disputatae (ed. Bajor), 67: „Proprie loquendo, tunc homo non generat hominem, quia nec materiam, nec generat formam, sed solum administrat ea, quae disponunt materiam pro introductione formae, sed dat materiam seminalem, quae disponit materiam pro introductione formae." 
probably knew the solutions he presented. In Quaestiones super De animalibus, Albert defines the participation of a human (mother and father) in giving birth, seeing the role of preparing the matter of a human embryo to accept a rational soul (form) that the First Cause creates ex nihilo and infuses into man (see Craemer-Ruegenberg 2005, 151-153; see also: Albertus MaGnus 1955, VII-X).

As a created form, the soul is introduced into a material body without the intermediary of an external cause. One may only speak here of an external efficient and final cause. ${ }^{38}$ The First Cause infuses one form into this matter, it is more noble and perfect than the form that nature could introduce to it. ${ }^{39}$

Interesting is the fragment of master Benedict's lecture in which he tries to soften the fact of the limited participation of man in the process of generation, somewhat "degraded" to a material dimension. He emphasizes that in the moment of the union of the soul with the body, the activity of the powers preparing the matter of man is suspended by the might of the divine will during the creation and infusion of the intellectual soul. ${ }^{40} \mathrm{He}$ carries out the following mental experiment: If God suspended in that moment the action of creation and left the matter of man in its natural state, not forming the intellect, would that matter be able to become a man or not? The answer is obviously negative, because matter in its natural state would not create an intellectual soul, but could very much so introduce (introducere) the sensitive form. This being so, one could say that man does not generate man and has a position worse than that of the donkey which generates a donkey. However, Hesse explains that man participates in the formation of the sensitive form which is much more perfect than the form of an animal. ${ }^{41}$

Benedict noted also in the form of the dubium the supernatural option of the explanation of this problem, in posing the question: Is the soul able to form an unformed body?

${ }^{38}$ Ibid., 53: "Ista accidentia seu qualitates dispositivae materiam non sunt causae intrinsecae unionis tamquam medium, per quod fit talis unio, sed sunt quaedam disponentia prima concurrentia ad talem unionem, quod forma uniatur materiae"; ibid., 48: "[...] ex anima et corpore fit unum essentialiter, et ergo quando materia est in ultima dispositione ad recipiendum formam, tunc forma immediate unitur ipsi materiae per se sine aliquo medio."

${ }^{39}$ Ibid., 67: „Natura seu qualitates dispositivae agunt pro introductione formae, et sic quando materia esset sufficienter disposita, tunc prima causa infundit in istam materiam unam formam, quae est nobilior et perfectior quam forma, quam natura deberet introducere."

${ }^{40}$ See ibid., 438.

${ }^{41}$ Ibid., 438: „Dicitur, quod tales virtutes existentes in materia producunt formam et hoc suspensa creatione, quia si non, tunc homo esset debilioris virtutis in generando quam asinus, quia homo non potest generare hominem, et tamen asinus generat asinum, scilicet per virtutes existentes in materia. Et ergo sequitur, quod homo etiam potest producere formam. Et dicitur ulterius, quod ista forma est sensitiva et haec forma est multo nobilior quam forma bruti." 
Although it is impossible in the natural state, because this is negated by the principle: actus activorum sunt in patiente bene praedisposito, Hesse, however, takes into account such a possibility in the supernatural dimension. Supernaturaliter loquendo, it is possibile that the soul forms an unorganized body, when by divine power it could be introduced into simple matter, that is, into an unorganized body actually, but aptitudinaliter, in order to organize that body for its formation. ${ }^{42}$ In the matter of the human body Benedict did not want to ignore another supernatural issue, namely concerning the resurrection of the body: Utrum possibile sit corpora mortuorum resurgere - despite the fact that in the introduction of this question he admits that we do not may give here a positive answer in a natural sense. ${ }^{43}$

\section{- THE EMBRYO AND SEMEN}

Linked to the problem of generation is also the problem of the nature of the semen and the question whether it differs from the embryo, strictly speaking, by what does the form of the semen differ from the form of the embryo, that is, the soul. In this question, Hesse follows Buridan who explains the difference between the human soul (form of the body) and the form of semen by accepting from Thomas Aquinas two kinds of potency: potentia propinqua and potentia remota. The soul differs from the substantial form of the semen because it is an act of the body possessing life in a potency near to (propinqua) the execution of life activities, as opposed to potency which semen possesses being a remote potency (remota), which means that it cannot execute life activities before a substantial change does not occur, by which a soul is born into it. Therefore, the definition of a soul does not pertain to the form of semen, because semen is not a potency near to the execution of life activities. ${ }^{44}$ Hesse mentions here as an example eggs

\footnotetext{
${ }^{42}$ Ibid., 47: „Sed supernaturaliter loquendo, tunc anima potest informare corpus non organisatum, quia per potentiam divinam potest infundere unam animam in simplicem materiam. Tamen potest dici, licet tale corpus non est organisatum actualiter, tamen bene potest esse organisatum aptitudinaliter sic, quod ista forma inquantum potest, organisaret illud corpus pro informatione sua."

${ }^{43}$ Benedict Hesse, Quaestiones disputatae super primum librum De anima Aristotelis (ed. Bajor = BeNEDICT Hesse 2000), 123: “[...] naturaliter loquendo corpora mortuorum totalia non possunt resurgere, sed supernaturaliter bene, quia per potentiam Divinam et supernaturalem, tunc corpora mortuorum resurgunt."

${ }^{44}$ JoAnnes Buridan, Le traité de l'âme (ed. Patar), 245: "Anima est actus corporis habentis vitam in potentia, id est corporis quod est in potentia propinqua ad exercendum operationes vitales, adhuc non convenit semini. Nam, quamvis semen sit corpus quod est in potentia ad exercendum
} 
and the seeds of corn (triticum), which do not fall under the definition of a soul, as unlike it they do not possess life activities neither in the sense of near potency, nor remote potency. ${ }^{45}$

The problem was also posed regarding which powers are contained in an embryo. Those in favour of a multiplicity of forms maintained that in the embryo it is the vegetable soul which is the first one formed, then the sensitive one, and later the intellectual soul. Buridan dismisses this argument, reducing it to an absurdity in the following understanding: accepting such a reason, it follows that from a wild animal without its destruction (absque eius corruptione) a man would issue by the arrival of a rational soul, then a hybrid would come about, composed of a wild animal (animali bruto) and a rational soul. ${ }^{46}$ Benedict Hesse duplicates a current argument of Buridan and his followers (already formulated by Albert the Great) ${ }^{47}$ against the thesis of the pluralists maintaining that the form is one, but the semblance of multiplicity appears from the cognitive conditionings: we first of all come to know the vegetative power, because it is the first to execute it activities, then we come to know the sensitive one, before we arrive at the knowledge of the intellectual power. ${ }^{48}$

\section{- DEATH AS A SEPARATION OF THE SOUL AND BODY}

In the question of human death, Hesse referred to the late mediaeval tradition concerning the exchange of forms at the moment of the separation of the body and soul. When the soul (intellect) leaves the body, its place is taken over by the form of the corpse (forma cadaveris), only the accidents of the body remain (e.g. warmth) (DE BOER 2013 170). The cause of death is in the body. Here we have a certain analogy. Just as in man's coming into being the matter of the human body (embryo) must be suitably prepared to receive the form - soul, so too when matter ceases to be adequately disposed, the intellect ceases to form it (intellectus desinit informare illam materiam) and death takes place. In explaining the phenomenon of death,

opera vitae, hoc tamen non est in potentia propinqua sed in potentia remota: non enim potest exercere opera vitalia nisi prius fiat transmutatio substantialis secundum quam generetur in ipso anima."

${ }^{45}$ See Benedict Hesse, Quaestiones disputatae (ed. Bajor), 38.

${ }^{46}$ See Joannes Buridan, Le traité de l'âme (ed. Patar), 542.

${ }^{47}$ See p. 41.

${ }^{48}$ Benedict Hesse, Quaestiones disputatae (ed. Bajor),, 25: “[...] quod in embrione nos prius percipimus potentiam vegetativam quam sensitivam sic, quod potentia vegetativa in embrione prius exerceret suas operationes quam intellectiva”. See Nicolaus ORESME 1995, 133. 
Benedict tried to reconcile naturalism with the postulates of faith. He accepted two kinds of destruction in respect of the separation of the soul from the body: relative and absolute (secundum quid and simpliciter). Thus, death understood as a destruction consisting of the separation of the soul and body, causes a relative destruction of the intellect. We may speak here of a destruction of its function of actual formation and inhesion (per destructionem informationis vel inhaesionis), but it keeps it in potency as this is possible in the light of the accepted inclination of the soul towards the body after their separation. Whereas, understanding destruction in an absolute sense, as annihilation and the end of existence, the intellect is not destructible. ${ }^{49}$ Here Hesse cautions that only in one case may one consider the annihilation of the intellect, namely, taking into account the theory of two kinds of divine power: ordinata i absoluta, God may accomplish this due to His absolute power, just as by His absolute power He called the soul to existence. ${ }^{50}$ However, in another place in his commentary, having distinguished two types of destruction - the natural and supernatural, he affirms: That which is destructible in the supernatural sense may all the more so last eternally, just as the intellect. ${ }^{51}$ This issues from the two meanings of the concept of generation accepted by Benedict: beings generated in the proper sense (proprie) created from non-being to being from potency of matter are destructible; whereas beings generated in the general sense (communiter) created from non-being to being in an absolute sense (simpliciter) just as the intellect which was created, are not destructible. ${ }^{52}$

Just as the generation of man, so too the moment of his death, treated as a substantial change, provoked questions regarding the ontological status of the basis of this change. The scholars of the $14^{\text {th }}$ century focused on the problem of the numerical identity of accidents and their durability in the pro-

${ }^{49}$ Benedict Hesse, Quaestiones disputatae (ed. Bajor), 355: "Quando creatur [intellectus], tamen post eius productionem requiritur qualificativas dispositiones si debet conservari in ipsa materia. Et ergo quando complexio qualificativa, conveniens per conservationem ipsius formae dissolvitur, tunc intellectus desinit informare illam materiam. Sed an intellectus corrumpitur, ibi respondetur: capiendo corruptionem pro separationem a materia, intellectus corrumpitur, vel pro illo, quod desinit esse, tunc non corrumpitur"; ibid., 380: "Sed quando dicitur - tunc intellectus semper inhaeret corpori, ibi respondetur, quod hoc est verum, quod intellectus semper inhaeret vel habet inclinationem ad inhaerentiam."

${ }^{50}$ Ibid., 435: "Intellectus humanus per potentiam Dei absolutam bene est anihilabilis, quia intellectus creatur a Deo, et ergo etiam potest anihilari, sed per potentiam Dei ordinatam, tunc intellectus non anihilatur."

${ }^{51}$ See ibid., 155.

${ }^{52}$ See ibid., 434-435. 
cess of generation and perishing, referring to Aristotle's De generatione et corruptione. Buridan defended strongly the thesis that in the process of the destruction of a composite being and a new production, the old accidents are preserved, for the reason that they are joined not to the substantial form, but to the matter. This standpoint was essential at least for two reasons. Firstly, in the question of generation, the assertion that the joining of the created soul (form) with the formed body does not entail with it a loss of its quality (although the form of the embryo perishes) strengthens the participation of man in generation and weakens dualism. For the soul forms a certain potentiality already marked by accidents. ${ }^{53}$ Secondly, this outlook gave a philosophical argument, in the discussed at the time doctrine of transubstantiation in the Eucharist where we are dealing with a substantial change (the body and blood of Christ) which is not accompanied by accidental changes (bread and wine).$^{54}$

Death understood as a separation of the soul from the body does not signify, from the point of view of Christian doctrine, neither the end of the soul's existence, not the ceasing of its relation with the body. Hence a further difficulty issues: How does one reconcile the philosophical concept of psycho-physical unity of man with the thesis of the immortality of the soul existing after its separation from the body? But this is a different subject discussed in the framework of the theory anima separata, going beyond the limits of my paper. ${ }^{55}$

\section{CONCLUSION}

Mediaeval scholars engaged in commenting on the peripatetic theory of the soul were aware that they were treading on the thin ice of one of the most difficult of philosophical domains. Aristotle himself preceded his psychological considerations in the treatise De Anima with a laconic remark, saying that the gaining of knowledge on the subject of the soul is "uncommonly difficult" (402a 11-13).

${ }^{53}$ In this matter, scholars describe Buridan's position differently: Benoit Patar contends that he is opposed to dualistic conceptions in which the soul and body play their role in separation, although he was also open to the dualistic option; it was his student, Nicole Oresme, who finally accepted it. See Nicolaus Oresme 1995, 177*. Whereas Zupko speaks of an immanent dualism of Buridan in explaining the soul-body relation. See ZUPKO 1993, 575, 591 and 600.

${ }^{54}$ See Joannes Buridan, Le traité de l'âme (ed. Patar), 139*; ibid., 236.

${ }^{55}$ On the concept of anima separata according to Hesse see more: BAJOR 2016, 113-127. 
The complicated problem of the origin (generation) of man and his death which takes up an essential part of science of the soul, constituted at the same time a neuralgic ideological element. Hence, mediaeval authors who attempted to link Aristotelian hylemorphism with Christian doctrine, added a third essential factor to the two factors of the process of generation presented in the Aristotelian statement-Homo generat hominem et sol,- - God, who creates a rational human soul and infuses it into the formed matter of the embryo. In this way the origin of man appears as a result of the cooperation of man, the sun and God. As regards human death, the accepted supernatural factor - the Creator of the human soul, guaranteed its individual immortality after its separation from the body.

Thinkers of the late Middle Ages, such as John Buridan and his continuators among which we also number such Cracovian scholars as Benedict Hesse, bearing in mind the whole load of epistemological difficulties posed by William Ockham, did not resign from a philosophical approach to scientia de anima, but attempted to develop the Aristotelian theory of the soul by giving it a new methodological dimension. The specificity of their outlook was the uniting of a more intense naturalistic option of research together with an opening up to the supernatural dimension of studied reality. They tried to find their solutions, while if they could not solve these aporeticals questions - they had the courage to admit, that is not possible by solely relying on the natural forces of reason. They had to refer to the teaching of christianity, without however falling prey to fideism. This was a methodical endeavour based on the experience that natural reason in searching for the truth is not capable of its own efforts to attain to certain concepts and might on occasion err, it is then that faith becomes its guide and supplies it with more acceptable solutions. This is the courage of one of the greatest philosophers - Plato, who said that you have to have this "great courage" to undertake only probable knowledge, when another is not possible.

\section{REFERENCES}

\section{PRimary Literature}

Albertus Magnus. 1955. Liber de natura et origine animae, edited by Bernhardus Geyer and Ephrem Filthaut. In Alberti Magni Opera Omnia, vol. XII, Münster: Aschendorff Verlag.

Aristoteles. 1831a. De anima. In Aristoteles latine interpretibus variis, edited by Academia Regia Borussica. Berolini: Apud Georgium Reimerum. 
ARISTOTELes. 1831b. De generatione animalium. In Aristoteles latine interpretibus variis, edited by Academia Regia Borussica. Berolini: Apud Georgium Reimerum.

Aristoteles. 1973. Ethica Nicomachea, edited by Renatus Antonius Gauthier. Leiden, Bruxelles: Brill.

Aristoteles. 1995. Metaphysica, recensio et translatio Guillelmi de Moerbeke. Editio textus, edited by Gudrun Vuillemin-Diem. In Aristoteles Latinus (ALPE XXV 3.2), Leiden: Brepols.

Benedict Hesse. 1984. Quaestiones super octo libros «Physicorum» Aristotelis, edited by Stanisław Wielgus. Wrocław: Zakład Narodowy im. Ossolińskich.

Benedict Hesse. 2011, Quaestiones disputatae super tres libros «De anima» Aristotelis (Libri II et III). Editio critica et inquisitio historico-philosophica, edited by Wanda Bajor, Lublin: Wydawnictwo KUL.

Benedict Hesse. 2000. Quaestiones disputatae super primum librum De anima Aristotelis Benedicti Hesse de Cracovia, edited by Wanda Bajor. Acta mediaevalia 14 (2000): 1-157.

Cajetan (Thomas de Vio). 1934. De Ente et essentia D. Thomae Aquinatis Commentaria, edited by Marie-Hyacinthe Laurent. Taurini: Marietti.

JoANNES Buridan. 1991. Le traité de l'âme de Jean Buridan [de prima lectura]. Édition, étude critique et doctrinale, ed. Benoît Patar, Louvain-la-Neuve: Éditions de l'Institut supérieur de philosophie; Longueuil, QC : Éditions du préambule, 1991.

Nicolaus Oresme. 1995. Nicolai Oresme Expositio et Quaestiones in Aristotelis De anima. Édition, étude critique, ed. Benoît Patar, Louvain-la-Neuve: Éditions de l'Institut supérieur de philosophie, Paris: Éditions Peeters.

Thomas Aquinas. 2019a. De spiritualibus creaturis, edited by Commissio Leonina, Textum Taurini 1953 editum et automato translatum a Roberto Busa SJ in taenias magneticas denuo recognovit Enrique Alarcón atque instruxit, Corpus Thomisticum. http://www.corpusthomisticum.org/ qds.html. Accessed 29 January, 2020.

Thomas Aquinas. 2019b. Quaestio disputata de anima, edited by Commissio Leonina, Textum Taurini 1953 editum et automato translatum a Roberto Busa SJ in taenias magneticas denuo recognovit Enrique Alarcón atque instruxit. Corpus Thomisticum. https://www.corpusthomisticum. org/qda01.html. Accessed 29 January, 2020.

Thomas Aquinas. 2019c. In librum B. Dionysii De divinis nominibus expositio, edited by Commissio Leonina, Textum Taurini 1950 editum et automato translatum a Roberto Busa SJ in taenias magneticas denuo recognovit Enrique Alarcón atque instruxit. Corpus Thomisticum. https://www.corpusthomisticum.org/cdn04.html. Accessed 29 January, 2020

Thomas Aquinas. 2019d. Summa contra gentiles, edited by Commissio Leonina, Textum Leoninum emendatum ex plagulis de prelo Taurini 1961 editum et automato translatum a Roberto Busa SJ in taenias magneticas denuo recognovit Enrique Alarcón atque instruxit. Corpus Thomisticum. http://www.corpusthomisticum.org/scg2056.html. Accessed 2 December, 2019.

William Oскнам. 1980. Quodlibeta septem, edited by Joseph C. Wey, Opera philosophica et theologica. Opera theologica, 9. St. Bonaventure, N.Y.: St. Bonaventure University.

\section{MANUSCRIPTS}

Anonymus. Quaestiones secundum scholam Joannis Buridani in I-III libros «De anima» Aristotelis, Ms BJ 1897 (Krakow), ff. 81r-187v.

Laurentius Lindores de Scotia. Quaestiones in I-III libros «De anima» Aristotelis, Ms BJ 705 (Krakow), ff. 183rb-271rb. 


\section{SECONDARY Literature}

AmerinI, Fabrizio. 2013. Aquinas on the Beginning and End of Human Life. Translated by Mark Henninger. Harvard: Harvard University Press.

BAJOR, Wanda. 2016. "The concept of anima separata in terms of the late-mediaeval via moderna." Studia Antyczne i Mediewistyczne 14 [49]: 113-127.

Bieniak, Magdalena. 2010. The Soul-Body Problem at Paris. CA. 1200-1250. Hugh of St-Cher and His Contemporares. Leuven: University Press.

Burrichter, Brigitte, and Thomas Dewender. 1988. "Die Diskussion der Frage nach der Unsterblichkeit in den «Quaestiones in libros De anima» des Benedikt Hesse von Krakau. In Die Philosophie im 14. und 15. Jahrhundert. In memoriam Konstanty Michalski (1879-1947). Bochumer Studien zur Philosophie 10: 573-602.

Courtenay, William J. 2008. Ockham and Ockhamism. Studies in the Dissemination and Impact of His Tought, Studien und Texte zur Geistesgeschichte des Mittelalters, 99. Leiden, Boston: Brill.

Craemer-Ruegenberg, Ingrid. 2005. “Albertus Magnus.” In Dominikanische Quellen und Zeugnisse, 7, edited by Henryk Anzulewicz. Lepzig: St. Benno-Verlag GmbH.

DA CRUz PonTes, José Maria. 1964. "Le problème de l'âme de la patristique à la solution thomiste." Recherches de théologie ancienne et médiévale 31 (Juillet-Décembre): 175-229.

DE Boer, Sander W. 2013. The Science of the Soul: The Commentary Tradition on Aristotle's De Anima c. 1260- c. 1360. Leuven: Leuven University Press.

Forest, Aimé. 1956. "La structure métaphysique du concret selon Saint Thomas d'Aquin." In Études de Philosophie Médiévale XIV, edited by Étienne Gilson. Paris: Librairie Philosophique J. Vrin.

KInG, Peter. 2017. "Later Medieval Philosophy of Cognitive Psychology." In Questions on the Soul by John Buridan and Others. A Companion to John Buridan Philosophy of Mind, edited by Guyla Klima. Historical-Analytical Studies on Nature, Mind and Action 3: 1-19.

Kunsewicz, Zdzisław. 1975. Filozofia człowieka. Teoria duszy. Dzieje filozofii średniowiecznej w Polsce, t. 5. Warszawa: Wydawnictwo Polskiej Akademii Nauk.

Markowski, Mieczysław. 1988. "Der Buridanismus an der Krakauer Universität im Mittelalter.” In Die Philosophie im 14. und 15. Jahrhundert. In memoriam Konstanty Michalski (1879-1947). Bochumer Studien zur Philosophie 10: 245-260.

MiCHALSKI, Konstanty. "Les courants philosophiques à Oxford et à Paris pendant le XIV ${ }^{\mathrm{e}}$ siècle." In Bulletin International de l'Académie Polonaise des Sciences et des Lettres, Cracow, 1921: 52-88.

Pasnau, Robert. 2007. "The Mind-Soul Problem." In Mind, Cognition and Representation: The Tradition of Commentaries on Aristotle's De anima, edited by Paul J.J.M. Bakker and Johannes M.M.H. Thijssen. Aldershot: Ashgate.

SwieżAwski, Stefan. 1948. "Centralne zagadnienie tomistycznej nauki o duszy." Przegląd Filozoficzny 44: 131-171.

Sylla, Edith. 2001. “Ideo quasi mendicare oportet intellectum humanum': The Role of Theology in John Buridan's Natural Philosophy." In Metaphysics and Natural Philosophy of John Buridan, edited by Johannes M.M.H. Thijssen and Jack Zupko, 225-245. Leiden, Boston. Köln: Brill.

ThiJssen, Johannes M.M.H., and Jack ZupKo (eds.). 2001. Metaphysics and Natural Philosophy of John Buridan, Leiden, Boston. Köln: Brill.

Wielgus, Stanisław. 1983. Benedykta Hessego Quaestiones super octo «Physicorum» Aristotelis (Wstęp do krytycznej edycji). Lublin: Redakcja Wydawnictw KUL. 
Wielgus, Stanisław. 2011. Benedykt Hesse. In: Encyklopedia Filozofii Polskiej, t. 1, edited by Andrzej Maryniarczyk, 94-96. Lublin: Polskie Towarzystwo Tomasza z Akwinu.

ZupKo, Jack. 1993. "How are Souls Related to Bodies? A Study of John Buridan." The Review of Metaphysics 46, no. 3: 575-601.

ZuPKo, Jack. John Buridan. Portrait of a Fourteenth-Century Arts Master, Notre Dame: Indiana, 2003.

\section{BODY-SOUL AND THE BIRTH AND DEATH OF MAN: BENEDICT HESSE'S OPINION IN THE MEDIAEVAL DISCUSSION}

\section{Sum mary}

This issue was discussed with regard to chosen commentaries to Aristotle's treatise De anima, formed in the so-called via moderna mainstream, in particular those of John Buridan, Nicole Oresme and Laurentius of Lindores. In such a context, the Cracovian commentaries referring to Parisian nominalists were presented by those of Benedict Hesse and Anonymus. The analyses carried out above allow one to ascertain that although William of Ockham's opinion questioning the possibility of knowledge of the soul in the field of philosophy, nominalists of the late Middle Ages did not resign from speculation on the beginning (birth) and the separation (death) from the body of the soul, also the fate of the soul after death. They focused on the nature of the matter - human body (embryo, semen) and his relation with the soul (forma) - in the moment of birth. In the aspect of death $14^{\text {th }}$ century scholars undertook the struggle, which was one with the justification of the psycho-physical unity of the human being existing after death solely as an immortal soul.

In both thems, they tried to find their solutions, while if they could not solve these aporeticals questions - they had the courage to admit, that is not possible by solely relying on the natural forces of reason. They had to refer to the teaching of christianity, without however falling prey to fideism. This was a methodical endeavour based on the experience that natural reason in searching for the truth is not capable of its own efforts to attain to certain concepts and might on occasion err, it is then that faith becomes its guide and supplies it with more acceptable solutions. This is the courage of one of the greatest philosophers - Plato, who said that you have to have this "great courage" to undertake only probable knowledge, when another is not possible.

Keywords: soul; human body; matter; birth; semen; embryo; death.

\section{CIAŁO-DUSZA A NARODZINY I ŚMIERĆ CZŁOWIEKA: OPINIA BENEDYKTA HESSEGO W ŚREDNIOWIECZNEJ DYSKUSJI}

\section{Streszczenie}

Przedstawiona problematyka została omówiona na podstawie wybranych komentarzy do traktatu Arystotelesa $O$ duszy, tworzonych w nurcie tzw. via moderna, zwłaszcza jego głównych przedsawicieli: Jana Burydana, Mikołaja Oresme i Londoriusza z Lindores. W tym kontekście powstały krakowskie komentarze m.in. Benedykta Hessego i Anonima, nawiązujące do paryskich nominalistów. Przeprowadzone analizy tekstów pozwalają stwierdzić, że mimo opinii Wilhelma Ockhama, kwestionującej możliwość filozoficznego poznania duszy, późnośredniowieczni zwolennicy nominalizmu nie rezygnowali ze spekulacji na temat początku człowieka (narodzin) i śmierci, czyli oddzielenia duszy od ciała, a także losu duszy po śmierci. Skupili się oni na naturze materii ludzkiego ciała (embrion, nasienie) i jego relacji do duszy (formy) - w momencie na- 
rodzin. W problematyce śmierci XIV-wieczni uczeni podjęli próby uzasadnienia psychofizycznej jedności istoty ludzkiej istniejącej po śmierci w postaci nieśmiertelnej duszy. Jeśli nie potrafili znaleźć zadowalającego rozwiązania tych aporetycznych kwestii, mieli odwagę przyznać, że nie jest to możliwe, polegając wyłącznie na naturalnych siłach rozumu. Wskazywali na konieczność odwołania się do wiary, nie popadając jednak w fideizm. Było to metodyczne przedsięwzięcie, oparte na doświadczeniu, że naturalny rozum ludzki w swych poszukiwaniach nie jest w stanie samodzielnie dojść do pewnych prawd i czasami może się mylić. Wówczas wiara staje się przewodnikiem i dostarcza bardziej akceptowalnych rozwiązań. To odwaga jednego z największych filozofów - Platona, który powiedział, że trzeba mieć „wielką odwagę”, aby podjąć się takich poszukiwań i przyjąć wiedzę tylko prawdopodobną, gdy wiedza pewna jest nieosiągalna.

Słowa kluczowe: dusza; ciało ludzkie; materia; narodziny; semen; embrion; śmierć.

Informacje o Autorze: Dr hab. WANDA BAJOR, prof. KUL - Katolicki Uniwersytet Lubelski Jana Pawła II, Wydział Filozofii, Instytut Filozofii, Katedra Historii Filozofii w Polsce; e-mail: bajor@kul.lublin.pl; ORCID: https://orcid.org/0000-0003-2121-0608. 